\title{
Efficacy and safety of intestinal secretagogues for chronic constipation: a systematic review and meta-analysis
}

\author{
Juan Sebastian LASA, María Josefina ALTAMIRANO, Luis Florez BRACHO, Silvina PAZ and \\ Ignacio ZUBIAURRE
}

Received 23/12/2017 Accepted 19/2/2018

\begin{abstract}
Background - Intestinal secretagogues have been tested for the treatment of chronic constipation and constipation-predominant irritable bowel syndrome. The class-effect of these type of drugs has not been studied. Objective-To determine the efficacy and safety of intestinal secretagogues for the treatment of chronic constipation and constipation-predominant irritable bowel syndrome. Methods - A computer-based search of papers from 1966 to September 2017 was performed. Search strategy consisted of the following MESH terms: intestinal secretagogues OR linaclotide OR lubiprostone OR plecanatide OR tenapanor OR chloride channel AND chronic constipation OR irritable bowel syndrome. Data were extracted as intention-to-treat analyses. A random-effects model was used to give a more conservative estimate of the effect of individual therapies, allowing for any heterogeneity among studies. Outcome measures were described as Relative Risk of achieving an improvement in the symptom under consideration. Results - Database Search yielded 520 bibliographic citations: 16 trials were included for analysis, which enrolled 7658 patients. Twelve trials assessed the efficacy of intestinal secretagogues for chronic constipation. These were better than placebo at achieving an increase in the number of complete spontaneous bowel movements per week [RR 1.87 (1.24-2.83)], at achieving three or more spontaneous bowel movements per week [RR 1.56 (1.311.85)] and at inducing spontaneous bowel movement after medication intake [RR 1.49 (1.07-2.06)]. Similar results were observed when assessing the efficacy of intestinal secretagogues on constipation-predominant irritable bowel syndrome based on the results of six trials. Conclusion - Intestinal secretagogues are useful and safe therapeutic alternatives for the treatment of constipation-related syndromes.
\end{abstract}

HEADINGS - Constipation. Irritable bowel syndrome. Colon.

\section{INTRODUCTION}

Chronic constipation (CC) as well as constipation-predominant irritable bowel syndrome (IBS-C) are very common conditions that constitute a frequent reason for referral to the general practitioner and the gastroenterology specialist ${ }^{(1)}$. These conditions are associated with a significant morbidity and an impaired quality of life ${ }^{(2)}$.

Even though they are classified as different entities according to Rome criteria ${ }^{(3)}$, the physiological mechanisms behind $\mathrm{CC}$ and IBS-C share a common ground. Thus, a diminished contractile activity of the colonic muscular layer as well as alterations in water reabsorption or secretion through intestinal epithelium have been proposed as etiological mechanisms ${ }^{(4)}$. As a consequence, they have been regarded as potential targets for pharmacological therapy.

Conventional treatment for CC and IBS-C include changes in lifestyle, increase of fiber intake and the use of a myriad of laxatives $^{(5)}$. It can also contemplate other therapies oriented to treat constipation-related symptoms, such as abdominal bloating or pain $^{(6)}$. It is noteworthy that a significant proportion of patients will not experience an improvement with these measures. Over the last years, new therapeutic alternatives have been developed: new high-affinity 5-HT4 receptor agonists such as prucalopride have been successfully tested; however, previous experience with similar molecules may raise a concern regarding their safety ${ }^{(7)}$.

Among these new alternatives, intestinal secretagogues have shown some promising results. These drugs are designed to increase intestinal fluid secretion, thus increasing bowel movement frequency as well as enhancing the amount of stool water ${ }^{(8)}$. These molecules can act at different points: linaclotide for instance is a guanylate cyclase- $\mathrm{C}$ agonist that activates the cystic fibrosis transmembrane conductance regulator in the intestinal epithelium ${ }^{(9)}$, whereas lubiprostone activates type 2 Chloride channels in the aforementioned cells ${ }^{(10)}$. The common pathway of these mechanisms is an increased release of chloride - and water - to the intestinal lumen.

These drugs have now been tested in different clinical settings for the treatment of both CC and IBS-C, and the preliminary results have triggered the development of drugs with similar mechanism of action, such as plecanatide or tenapanor ${ }^{(11)}$. The class-effect of these type of drugs has not been extensively studied. As a consequence, we sought to determine the efficacy and safety of intestinal secretagogues for the treatment of CC and IBS-C.

Declared conflict of interest of all authors: none

Disclosure of funding: no funding received

Gastroenterology Department. Hospital Britanico de Buenos Aires. Buenos Aires, Argentina

Corresponding author: Juan Sebastian Lasa. E-mail: juanselasa@gmail.com 


\section{METHODS}

\section{Search strategy and study selection}

A computer-based search of compatible papers from 1966 to November 2017 was performed using the following databases: MEDLINE-Pubmed, EMBASE, LILACS and The Cochrane Library. Search strategy consisted of the following MeSH terms: intestinal secretagogues OR linaclotide OR lubiprostone OR plecanatide OR tenapanor OR chloride channel AND chronic constipation OR irritable bowel syndrome.

Relevant paper's bibliographies were revised, as well as bibliographies from previously published meta-analyses. A manual search for potentially relevant abstracts from Digestive Disease Week and United European Gastroenterology Week from 20092017 was also undertaken.

Two authors performed bibliographic search in an independent manner. Potentially relevant abstracts were revised in order to check its inclusion. Inclusion criteria were: a) trials examining the efficacy of any intestinal secretagogue for CC and/or IBS-C treatment; b) randomized, placebo-controlled trials; c) trials performed on adults. There were no language restrictions.

Search findings were then compared. If there was disagreement on the inclusion of a particular trial, it was discussed and determined by consensus. If there was evidence of duplication of data, the main author would be contacted to determine its inclusion.

\section{Methodological evaluation of included studies}

Methodological assessment was done using the Evidence-Based Gastroenterology Steering Group recommendations ${ }^{(12)}$. A Jadad score of each trial was also calculated. If a significant difference in methodological quality among studies was observed, a sensitivity analysis would be undertaken by excluding those trials with less quality. If relevant data was missing in original manuscripts, authors would be contacted.

\section{Outcome measures}

The following outcomes were considered for analysis: three or more spontaneous bowel movements (SBM) per week, number of complete spontaneous bowel movements (CSBM) per week, SBM after medication administration, improvement in abdominal pain, global relief of symptoms. Since Rome IV criteria( ${ }^{(3)}$ disregard abdominal discomfort as a pivotal symptom for the definition of IBS, we decided that it should not be contemplated as an endpoint, even though most trials assessed this point in particular. Data were extracted as intention-to-treat analyses, in which all dropouts are assumed to be treatment failures, wherever trial reporting allowed this.

\section{Statistical analysis}

Meta-analysis was performed using REVMAN software (Review Manager Version 5.2. Copenhagen: The Nordic Cochrane Collaboration, 2012). Heterogeneity among studies was evaluated by means of chi square and $\mathrm{I} 2$ tests. A random-effects model was used to give a more conservative estimate of the effect of individual therapies, allowing for any heterogeneity among studies. Outcome measures were described as relative risk (RR) of achieving an improvement in the symptom under consideration. Also, 95\% confidence intervals were calculated. Funnel plots were designed to evaluate possible publication bias. Numbers necessary to treat (NNT) were calculated.

\section{RESULTS}

Database Search yielded 520 bibliographic citations, as shown in FIGURE 1. Of these, 18 full texts were assessed for eligibility and 16 trials were finally included for analysis ${ }^{(13-27)}$, which enrolled 7658 patients.

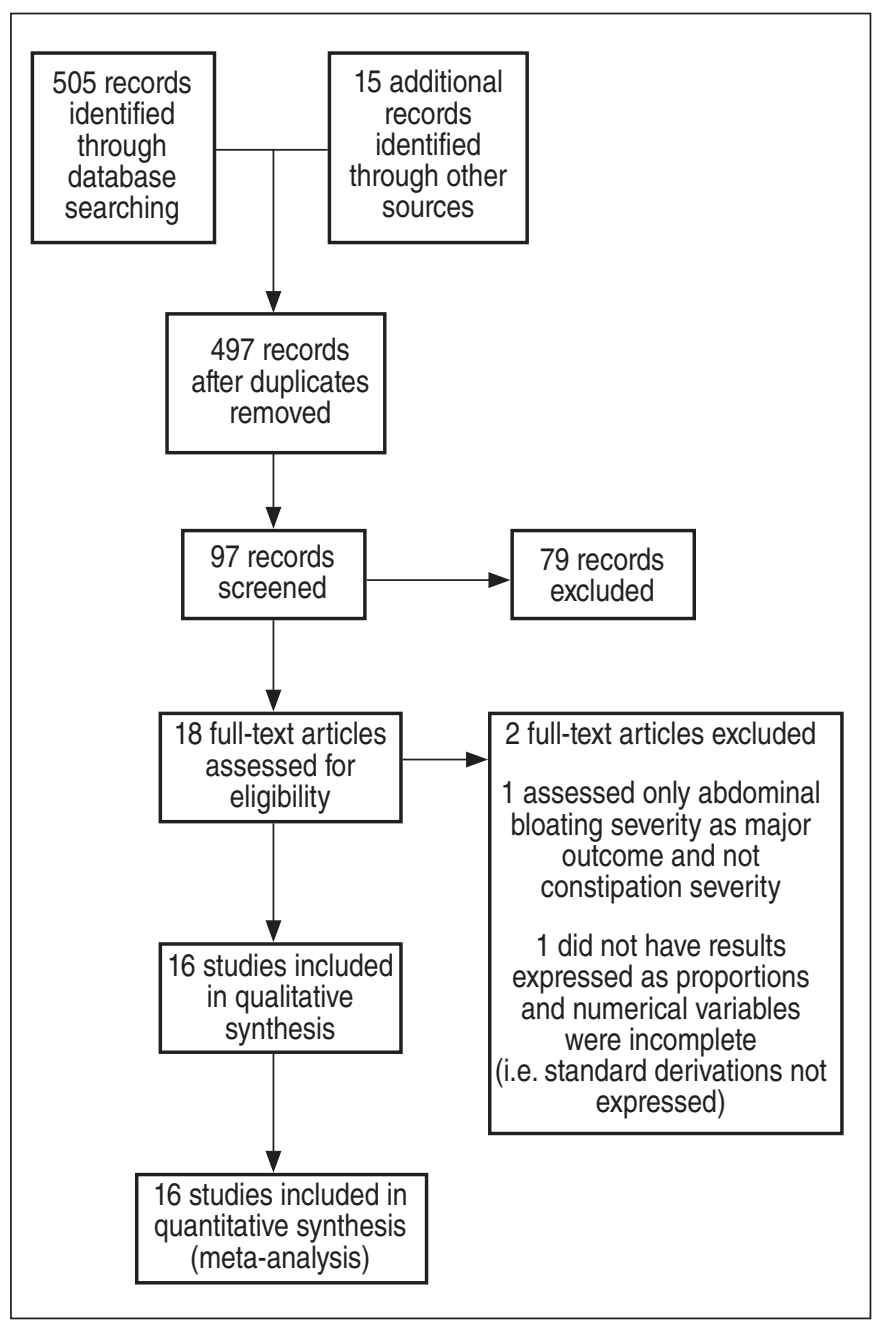

FIGURE 1. Flow chart showing the results of the bibliographic search and final selection of inc luded studies.

The main characteristics of included trials are described in TABLE 1. One of the most challenging aspects of this systematic review was the heterogeneity in the assessment of experimental drugs efficacy: as a consequence, not every trial was included in the assessment of each of the endpoints considered for meta-analysis. Patients were not similar: from an etiologic point of view, we divided trials evaluating the efficacy and safety of intestinal secretagogues on patients with CC and with IBS-C. Furthermore, CC patients also included patients with opioid-induced constipation as well as constipation associated with Parkinson disease ${ }^{(21)}$ and diabetes mellitus ${ }^{(25)}$.

Methodological evaluation of included trials is described in TABLE 2. No trial was excluded due to methodological limitations. No significant publication bias was found according to the Egger test $(P>0.5)$. 
TABLE 1. Main characteristics of included studies.

\begin{tabular}{|c|c|c|c|c|c|c|}
\hline $\begin{array}{l}\text { Author } \\
\text { (Year) }\end{array}$ & Countrie & $\begin{array}{l}\text { Age (median), } \\
\text { Gender }(\% \mathrm{~F}) \\
\text { and Diagnosis }\end{array}$ & Outcome Measures & Number of Patients & Interventions & $\begin{array}{l}\text { Co- } \\
\text { Interventions }\end{array}$ \\
\hline \multicolumn{7}{|c|}{ LINACLOTIDE } \\
\hline $\begin{array}{l}\text { Johnston } \\
2010\end{array}$ & $\begin{array}{l}\text { USA/ } \\
\text { Canada }\end{array}$ & $\begin{array}{l}44.4 / 92 \% \\
\text { CIC+IBS-C }\end{array}$ & $\begin{array}{l}\% \text { of patients with CBM; } \% \text { of patients with } \\
>3 \text { BM during } 75 \% \text { of treatment period; } \% \text { of } \\
\text { patients with Bristol Score }>3 ; \% \text { of patients } \\
\text { without significant constipation; abdominal } \\
\text { pain severity; abdominal bloating severity; } \% \text { of } \\
\text { patients with global relief }\end{array}$ & $\begin{array}{l}85 \text { patients on placebo; } 79 \\
\text { on linaclotide } 75 \mathrm{ug} ; 82 \text { on } \\
\text { linaclotide } 150 \mathrm{ug} ; 84 \text { on } \\
\text { linaclotide } 300 \mathrm{ug} ; 89 \text { on } \\
\text { linaclotide } 600 \mathrm{ug}\end{array}$ & $\begin{array}{l}\text { Linaclotide once } \\
\text { per day or placebo } \\
\text { for } 12 \text { weeks }\end{array}$ & $\begin{array}{l}\text { Bisacodyl or } \\
\text { phosphate } \\
\text { enema as rescue } \\
\text { medication }\end{array}$ \\
\hline $\begin{array}{l}\text { Lembo } \\
2010\end{array}$ & USA & $47.3 / 92 \% / \mathrm{CIC}$ & $\begin{array}{l}\% \text { of patients with CBM; } \% \text { of patients with } \\
\text { SBM; } \% \text { of patients with Bristol Score }>3 ; \\
\% \text { of patients without significant straining; } \\
\text { abdominal pain and bloating severity; } \% \text { of } \\
\text { patients with global relief }\end{array}$ & $\begin{array}{l}68 \text { patients on placebo; } 59 \\
\text { on linaclotide } 75 \mathrm{ug} ; 56 \text { on } \\
\text { linaclotide } 150 \mathrm{ug} ; 62 \text { on } \\
\text { linaclotide } 600 \mathrm{ug}\end{array}$ & $\begin{array}{l}\text { Oral linaclotide } \\
\text { once daily or } \\
\text { placebo for } 4 \\
\text { weeks }\end{array}$ & $\begin{array}{l}\text { Bisacodyl or } \\
\text { phosphate } \\
\text { enema as rescue } \\
\text { medication }\end{array}$ \\
\hline $\begin{array}{l}\text { Lembo } \\
2011\end{array}$ & $\begin{array}{l}\text { USA and } \\
\text { Canada } \\
\text { (2 clinical } \\
\text { trials })\end{array}$ & $\begin{array}{l}47.8 / 89.7 \% 1 \\
\text { CIC }\end{array}$ & $\begin{array}{c}\% \text { of patients with }>3 \text { CSBM in } 9 \text { out of } 12 \\
\text { weeks and/or increase in }>1 / \text { week; } \% \text { of patients } \\
\text { with SBM after medication intake; } \% \text { of } \\
\text { patients with }>2 \text { SBM/week; } \% \text { of patients with } \\
\text { global relief }\end{array}$ & $\begin{array}{l}424 \text { patients on placebo; } \\
430 \text { on linaclotide } 145 \mathrm{ucg} \\
418 \text { on linaclotide } 290 \text { ucg }\end{array}$ & $\begin{array}{l}\text { Linaclotide or } \\
\text { placebo for } 12 \\
\text { weeks }\end{array}$ & Not clear \\
\hline $\begin{array}{l}\text { Chey } \\
2012\end{array}$ & USA & $\begin{array}{l}44.3 / 89.55 \% / \\
\text { IBS-C }\end{array}$ & $\begin{array}{c}\% \text { of patients with pain severity improvement } \\
\text { of }>30 \% \text { for at least } 6 \text { out of } 12 \text { weeks; } \% \text { of } \\
\text { patients with }>1 \text { CSBM/week for at least } 6 \text { out } \\
\text { of } 12 \text { weeks; } \% \text { of patients with }>3 \text { CBM/week; } \\
\% \text { of patients with CSBM after medication } \\
\text { intake; } \% \text { of patients with }>2 \text { SBM/week; } \% \\
\text { of patients with Bristol Score }>3 ; \% \text { of patients } \\
\text { with global relief }\end{array}$ & $\begin{array}{l}403 \text { patients on placebo; } \\
402 \text { on linaclotide } 290 \text { ucg }\end{array}$ & $\begin{array}{l}\text { Linaclotide or } \\
\text { placebo for } 26 \\
\text { weeks (assessment } \\
\text { after } 12 \text { weeks of } \\
\text { completion) }\end{array}$ & Not clear \\
\hline $\begin{array}{l}\text { Rao } \\
2012\end{array}$ & $\begin{array}{l}\text { USA and } \\
\text { Canada }\end{array}$ & $\begin{array}{l}43.5 / 90.5 \% 1 \\
\text { IBS-C }\end{array}$ & $\begin{array}{l}\% \text { of patients with pain severity improvement } \\
>30 \% \text { for at least } 6 \text { out of } 12 \text { weeks; } \% \text { of } \\
\text { patients with }>1 \mathrm{CSBM} / \text { week for } 6 \text { out of } 12 \\
\text { weeks; } \% \text { of patients with }>3 \mathrm{CBM} / \text { week; } \% \text { of } \\
\text { patients with SBM after medication intake; } \% \\
\text { of patients }>2 \mathrm{SBM} / \text { week; } \% \text { of patients with } \\
\text { Bristol Score }>3 ; \% \text { of patients with global relief }\end{array}$ & $\begin{array}{l}395 \text { patients on placebo; } \\
405 \text { patients on linaclotide } \\
290 \text { ucg }\end{array}$ & $\begin{array}{l}\text { Linaclotide or } \\
\text { placebo for } 12 \\
\text { weeks }\end{array}$ & $\begin{array}{l}\text { Oral or rectal } \\
\text { bisacodyl as } \\
\text { rescue treatment }\end{array}$ \\
\hline \multicolumn{7}{|c|}{ LUBIPROSTONE } \\
\hline $\begin{array}{l}\text { Johanson } \\
2008\end{array}$ & USA & $\begin{array}{l}48.27 / 90.55 \% / \\
\text { CIC }\end{array}$ & $\begin{array}{c}\% \text { of patients with SBM; straining severity score; } \\
\text { Bristol score; bloating and abdominal discomfort } \\
\text { severity; \% of patients who required rescue } \\
\text { treatment }\end{array}$ & $\begin{array}{l}33 \text { patients on placebo; } 30 \\
\text { on lubiprostone } 24 \mathrm{mcg} ; 32 \\
\text { on lubiprostone } 48 \mathrm{mcg} ; 34 \\
\text { on lubiprostone } 72 \mathrm{mcg}\end{array}$ & $\begin{array}{l}\text { Lubiprostone or } \\
\text { placebo T.I.D. for } \\
\quad 3 \text { weeks }\end{array}$ & $\begin{array}{l}\text { Oral bisacodyl } \\
\text { or sodium } \\
\text { phosphate } \\
\text { enema as rescue } \\
\text { treatment }\end{array}$ \\
\hline $\begin{array}{l}\text { Drossman } \\
2008\end{array}$ & USA & $\begin{array}{l}46.6 / 91.6 \% / \\
\text { IBS-C }\end{array}$ & $\begin{array}{l}\% \text { of patients with global improvement of } \\
\text { IBS symptom severity: SBM, } \\
\text { abdominal pain and bloating }\end{array}$ & $\begin{array}{l}385 \text { patients on placebo; } \\
769 \text { on lubiprostone } 8 \mathrm{mcg}\end{array}$ & $\begin{array}{l}\text { Lubiprostone or } \\
\text { placebo T.ID. for } \\
12 \text { weeks }\end{array}$ & $\begin{array}{l}\text { Oral bisacodyl } \\
\text { or sodium } \\
\text { phosphate } \\
\text { enema as rescue } \\
\text { treatment }\end{array}$ \\
\hline $\begin{array}{l}\text { Fukudo } \\
2011\end{array}$ & Japan & $\begin{array}{c}39.4 / 90.58 \% 1 \\
\text { CIC + IBS-C }\end{array}$ & $\begin{array}{l}\text { P\% of patients with SBM after medication } \\
\text { intake; } \% \text { of patients with global relief }\end{array}$ & $\begin{array}{l}42 \text { patients on placebo; } \\
41 \text { on lubiprostone } 16 \mathrm{mcg} \text {; } \\
43 \text { on lubiprostone } 32 \mathrm{mcg} \text {; } \\
44 \text { on lubiprostone } 48 \mathrm{mcg}\end{array}$ & $\begin{array}{l}\text { Lubiprostone } \\
\text { or placebo for } 2 \\
\text { weeks }\end{array}$ & $\begin{array}{c}\text { Bisacodyl } \\
\text { suppositories } \\
\text { or glycerol } \\
\text { enema as rescue } \\
\text { treatment }\end{array}$ \\
\hline $\begin{array}{l}\text { Ondo } \\
2012\end{array}$ & USA & $\begin{array}{c}67.3 / 24.59 \% / \\
\text { Constipation } \\
\text { on Parkinson } \\
\text { patients }\end{array}$ & $\begin{array}{l}\% \text { of patients with global relief; number of } \\
\text { SBM/week with medication }\end{array}$ & $\begin{array}{l}31 \text { patients on placebo; } \\
30 \text { on lubiprotsone } 24 \mathrm{mcg}\end{array}$ & $\begin{array}{l}\text { Lubiprostone or } \\
\text { placebo B.I.D. for } \\
\quad 4 \text { weeks }\end{array}$ & Not clear \\
\hline $\begin{array}{l}\text { Cryer } \\
2014\end{array}$ & $\begin{array}{l}\text { USA and } \\
\text { Canada }\end{array}$ & $\begin{array}{l}50.4 / 64.35 \% / \\
\text { opiod-induced } \\
\text { constipation }\end{array}$ & $\begin{array}{c}\% \text { of patients with SBM after medication intake; } \\
\% \text { of patients with }>3 \mathrm{SBM} / \text { week for at least } \\
50 \% \text { of treatment duration }\end{array}$ & $\begin{array}{l}208 \text { patients on placebo; } \\
210 \text { patients on } \\
\text { lubiprostone } 24 \mathrm{mcg}\end{array}$ & $\begin{array}{l}\text { Lubiprostone or } \\
\text { placebo B.I.D. for } \\
12 \text { weeks }\end{array}$ & $\begin{array}{l}\text { Oral bisacodyl } \\
\text { or sodium } \\
\text { phosphate } \\
\text { enema as rescue } \\
\text { treatment }\end{array}$ \\
\hline $\begin{array}{l}\text { Fukudo } \\
2015\end{array}$ & Japan & $\begin{array}{l}42.1 / 87.9 \% / \\
\text { CIC }\end{array}$ & $\begin{array}{c}\% \text { of patients with SBM after medication intake; } \\
\% \text { of patients with }>4 \mathrm{SBM} / \text { week; } \\
\text { constipation severity }\end{array}$ & $\begin{array}{l}62 \text { patients on placebo; } \\
62 \text { patients on lubiprostone } \\
48 \mathrm{mcg}\end{array}$ & $\begin{array}{l}\text { Lubiprostone or } \\
\text { placebo for } \\
4 \text { weeks }\end{array}$ & $\begin{array}{c}\text { Bisacodyl } \\
\text { suppositories } \\
\text { or glycerol } \\
\text { enema as rescue } \\
\text { treatment }\end{array}$ \\
\hline
\end{tabular}




\begin{tabular}{|c|c|c|c|c|c|c|}
\hline $\begin{array}{l}\text { Jamal } \\
2015\end{array}$ & $\begin{array}{l}\text { USA and } \\
\text { Europe }\end{array}$ & $\begin{array}{l}51.7 / 63.11 \% / \\
\text { opioid-induced } \\
\text { constipation }\end{array}$ & $\%$ of patients with SBM after medication intake & $\begin{array}{l}217 \text { patients on placebo; } \\
214 \text { on lubiprostone } \\
24 \text { mcg BID }\end{array}$ & $\begin{array}{l}\text { Lubiprostone or } \\
\text { placebo B.I.D. for } \\
12 \text { weeks }\end{array}$ & $\begin{array}{l}\text { Oral bisacodyl } \\
\text { or sodium } \\
\text { phosphate } \\
\text { enema as rescue } \\
\text { treatment }\end{array}$ \\
\hline $\begin{array}{l}\text { Christie } \\
2017\end{array}$ & USA & $\begin{array}{l}56.7 / 65.5 \% / \\
\text { constipation } \\
\text { on diabetic } \\
\text { patients }\end{array}$ & $\begin{array}{l}\% \text { of patients with CSBM; } \\
\text { average number of SBM/week }\end{array}$ & $\begin{array}{l}39 \text { patients on placebo / } \\
37 \text { patients on lubiprostone } \\
24 \text { mcg BID }\end{array}$ & $\begin{array}{l}\text { Lubiprostone or } \\
\text { placebo B.I.D. for } \\
\quad 8 \text { weeks }\end{array}$ & $\begin{array}{l}\text { Laxatives } \\
\text { (including } \\
\text { PEG) as rescue } \\
\text { treatment }\end{array}$ \\
\hline \multicolumn{7}{|c|}{ PLECANATIDE } \\
\hline $\begin{array}{l}\text { Miner } \\
2017\end{array}$ & $\begin{array}{l}\text { USA and } \\
\text { Canada }\end{array}$ & $\begin{array}{c}45.4 / 80.75 \% / \\
\text { CIC }\end{array}$ & $\begin{array}{l}\% \text { of patients with }>3 \mathrm{CSBM} \text { and/or increase in } \\
\mathrm{SBM} / \text { week in } 9 \text { out of } 12 \text { weeks of treatment; } \\
\% \text { of patients with SBM after medication intake }\end{array}$ & $\begin{array}{l}452 \text { patients on placebo; } \\
452 \text { on plecanatide } 3 \mathrm{mg} \\
441 \text { on plecanatide } 6 \mathrm{mg}\end{array}$ & $\begin{array}{l}\text { Plecanatide or } \\
\text { placebo once daily } \\
\text { for } 12 \text { weeks }\end{array}$ & $\begin{array}{l}\text { Bisacodyl as } \\
\text { rescue treatment }\end{array}$ \\
\hline \multicolumn{7}{|c|}{ TENAPANOR } \\
\hline $\begin{array}{l}\text { Chey } \\
2017\end{array}$ & USA & $\begin{array}{l}45.7 / 86.8 \% / \\
\text { IBS-C }\end{array}$ & $\begin{array}{l}\% \text { of patients with }>\mathrm{SBM} / \text { week for at least } 50 \% \\
\text { of the treatment duration; } \% \text { of patients with } \\
>30 \% \text { decrease of abdominal pain severity for at } \\
\text { least } 50 \% \text { of the treatment duration }\end{array}$ & $\begin{array}{l}89 \text { patients on placebo; } 85 \\
\text { on tenapanor } 5 \mathrm{mg} ; 87 \text { on } \\
\text { tenapanor } 20 \mathrm{mg} ; 84 \text { on } \\
\text { tenapanor } 50 \mathrm{mg} \text { BID }\end{array}$ & $\begin{array}{l}\text { Tenapanor or } \\
\text { placebo B.I.D. for } \\
12 \text { weeks }\end{array}$ & $\begin{array}{l}\text { Bisacodyl or } \\
\text { suppositories as } \\
\text { rescue treatment }\end{array}$ \\
\hline
\end{tabular}

CIC: chronic idiopathic constipation; IBS-C: constipation-predominant irritable bowel syndrome; CBM: complete bowel movement; SBM: spontaneous bowel movement; CSBM: complete spontaneous bowel movement; B.I.D: bis in die.

TABLE 2. Methodological features of included studies.

\begin{tabular}{|c|c|c|c|c|c|c|}
\hline Study ID & $\begin{array}{l}\text { Concealed } \\
\text { allocation }\end{array}$ & $\begin{array}{c}\text { Blinding of patients } \\
\text { and healthcare } \\
\text { personnel }\end{array}$ & $\begin{array}{c}\text { Equalco- } \\
\text { interventions } \\
\text { between groups }\end{array}$ & Follow up report & $\begin{array}{c}\text { Intention to treat } \\
\text { analysis }\end{array}$ & $\begin{array}{l}\text { Jadad } \\
\text { score }\end{array}$ \\
\hline \multicolumn{7}{|l|}{ LINACLOTIDE } \\
\hline Lembo 2010 & Yes & Yes & Yes & Yes & Yes & 7 \\
\hline Lembo 2011 & Yes & Yes & Yes & Yes & Yes & 7 \\
\hline Rao 2012 & Yes & Yes & Yes & Yes & Yes & 7 \\
\hline \multicolumn{7}{|c|}{ LUBIPROSTONA } \\
\hline Johanson 2007 & Not clear & Yes & Yes & Yes & Yes & 6 \\
\hline Drossman 2008 & Not clear & Yes & Yes & Yes & Yes & 6 \\
\hline Fukudo 2010 & Not clear & Yes & Yes & Yes & No & 6 \\
\hline Jamal 2015 & Yes & Yes & Yes & Yes & Yes & 7 \\
\hline Christie 2017 & Not clear & Yes & Yes & Yes & Not clear & 6 \\
\hline \multicolumn{7}{|c|}{ PLECANATIDE } \\
\hline Miner 2017 & Yes & Yes & Yes & Yes & Yes & 7 \\
\hline \multicolumn{7}{|l|}{ TENAPANOR } \\
\hline Chey 2017 & Yes & Yes & Yes & Yes & Yes & 7 \\
\hline
\end{tabular}

\section{Efficacy of intestinal secretagogues for patients with chronic constipation}

Twelve randomized controlled trials assessed the efficacy of three drugs for CC patients: linaclotide (Johnston 2010, Lembo 2010 and the two controlled trials published in Lembo 2011), lubiprostone (Johanson 2007, Fukudo 2011, Ondo 2012, Cryer 2014, Fukudo 2015, Jamal 2015 and Christie 2017) and plecanatide (Miner 2017). Efficacy endpoints are described in FIGURE 2. Overall, intestinal secretagogues were better than placebo at achieving an increase in the number of CSBM per week [RR 1.87 (1.24-2.83), NNT 9], also at achieving three or more SBM per week [RR 1.56 (1.311.85), NNT 6] and at inducing SBM after medication intake [RR 1.49 (1.07-2.06), NNT 6]. Additionally, patients treated with intestinal secretagogues experienced a more significant global relief of their symptoms compared to placebo [RR 1.78 (1.18-2.69), NNT 7]. In the cases where a significant heterogeneity was found, a sensitivity analysis was performed, showing no significant changes. 


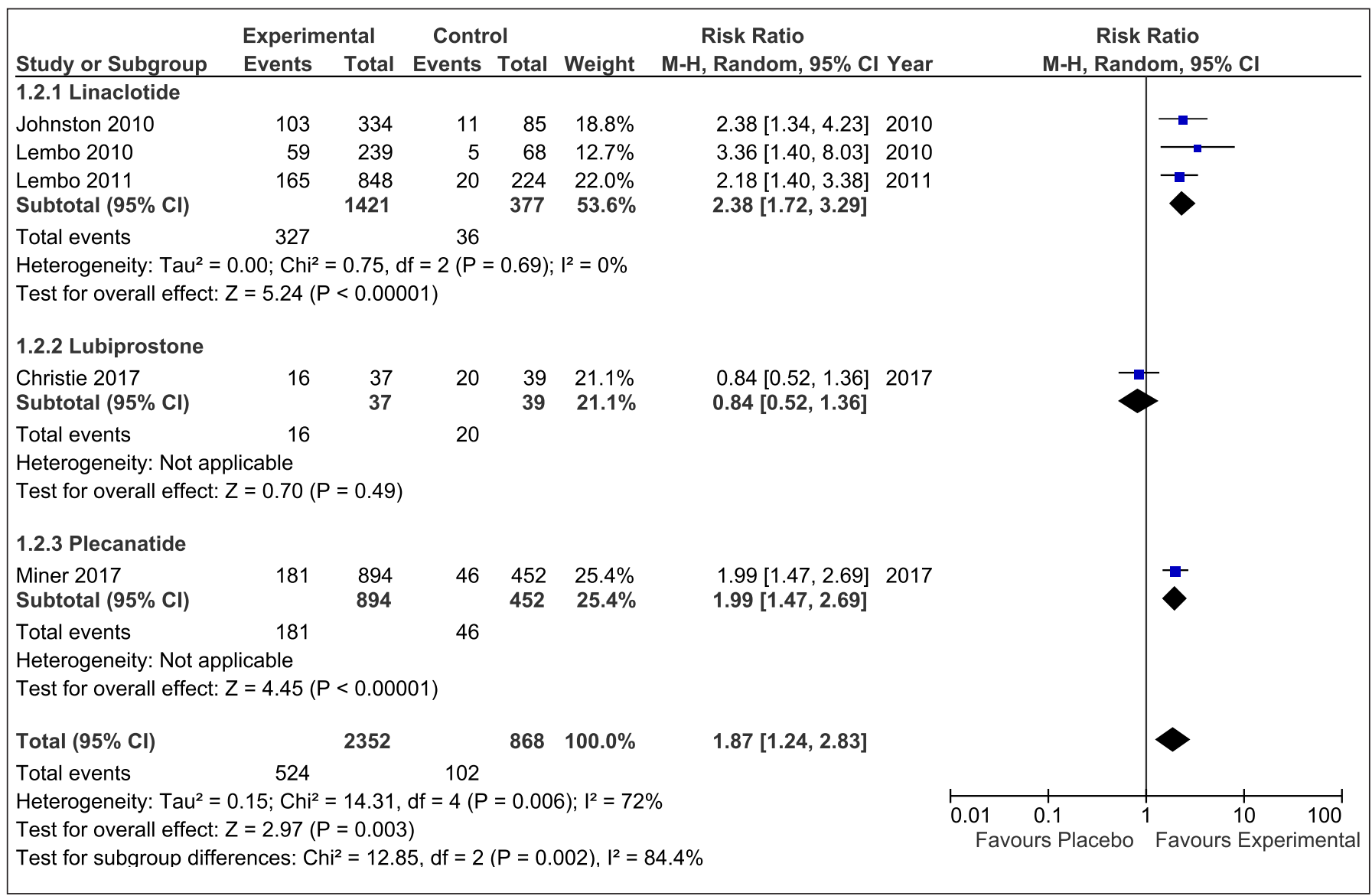

FIGURE 2. Efficacy of intestinal secretagogues on chronic idiopathic constipation patients, based on the following endpoints: A) Increase in the number of CSBM per week.

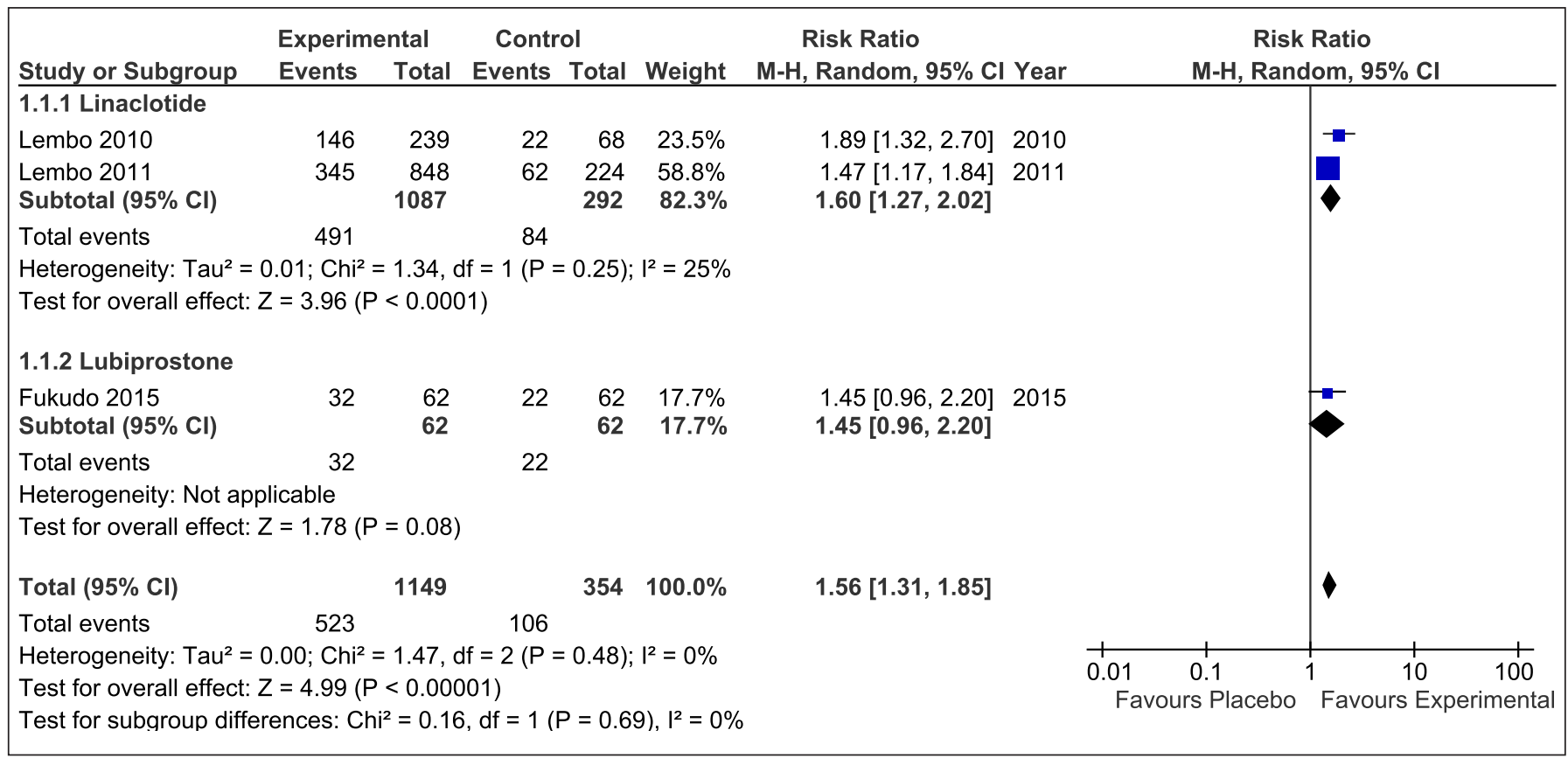

FIGURE 2. B) Achievement of >3 SBM per week. 


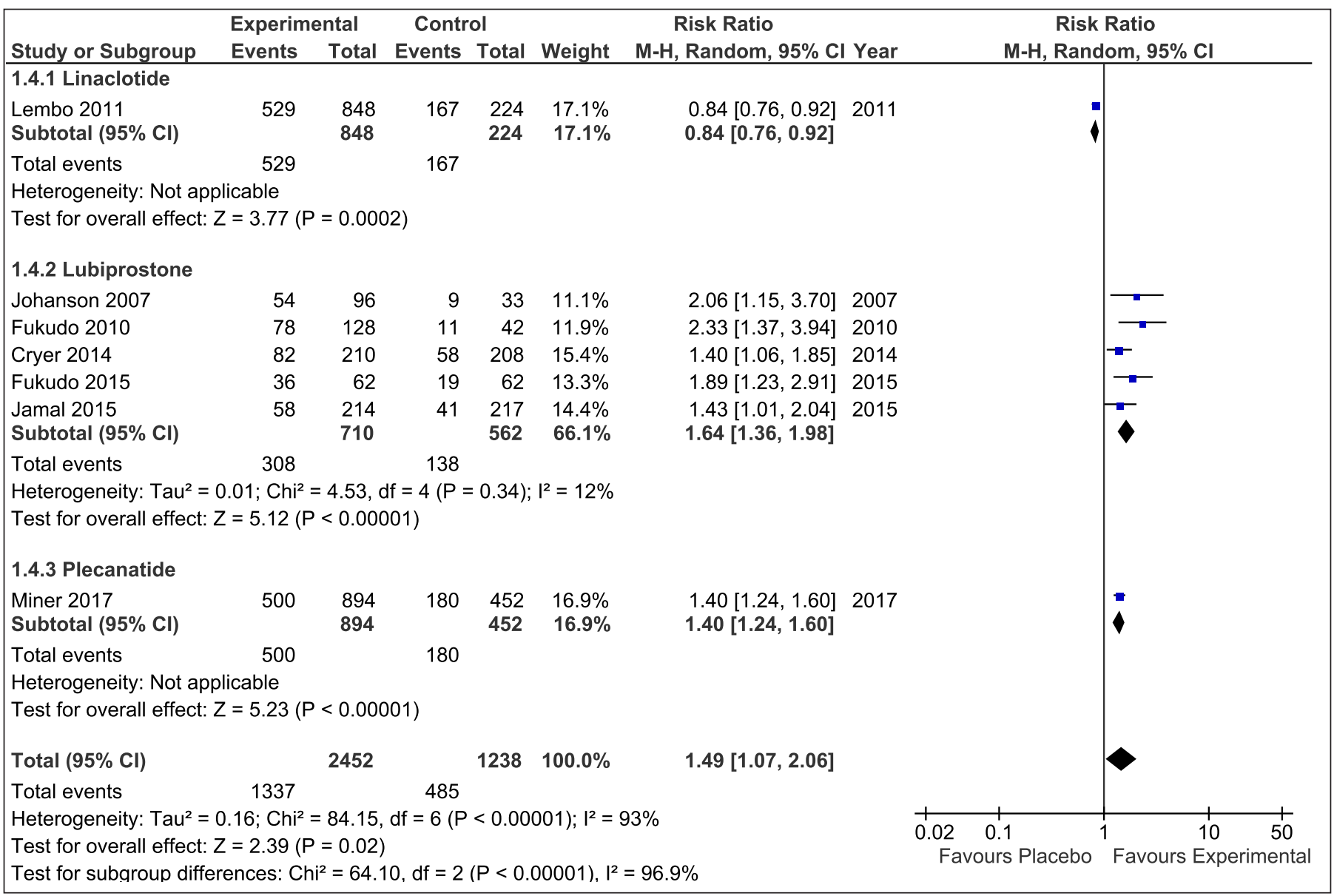

FIGURE 2. C) SBM after medication intake.

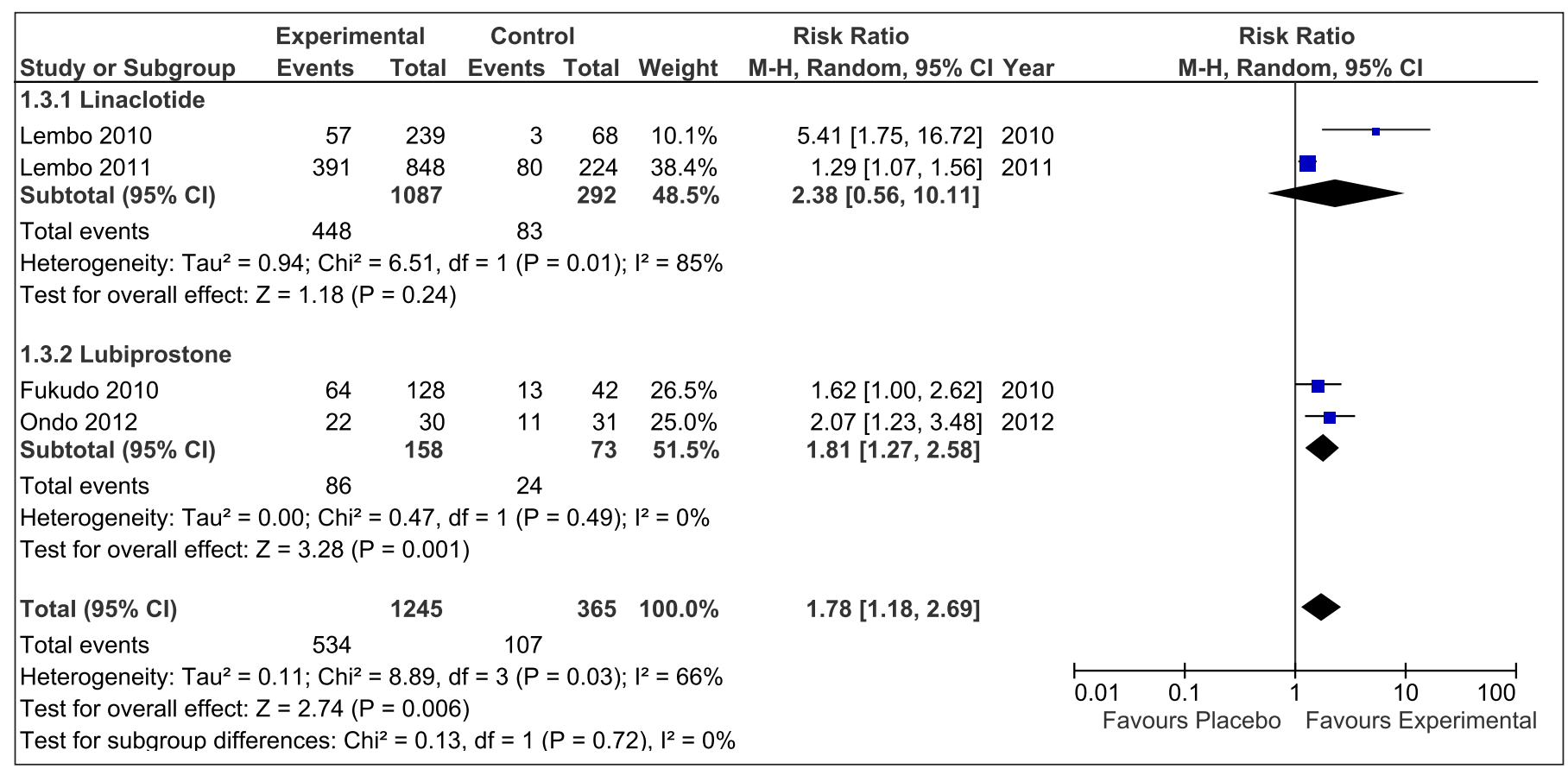

FIGURE 2. D) Achievement of global relief. 
Efficacy of intestinal secretagogues for patients with constipation-predominant irritable bowel syndrome

Six randomized controlled trials assessed the efficacy of three drugs for IBS-C patients: linaclotide (Johnston 2010, Rao 2012, Chey 2012), lubiprostone (Fukudo 2011, Drossmann 2009) and tenapanor (Chey 2017). Efficacy endpoints are described in FIGURE 3. Intestinal secretagogues were not only better at achieving a relief in constipation-related outcomes such as increase in CSBM [RR 2.44 (1.51-3.93), NNT 5], three or more SBM per week [RR 1.97 (1.74-2.24), NNT 3], SBM after medication intake [RR 1.60 (1.44-1.79), NNT 4], but also a significant improvement in ab- dominal pain was observed versus placebo [RR 1.34 (1.21-1.48), NNT 9]. In the cases where a significant heterogeneity was found, a sensitivity analysis was performed, showing no significant changes.

\section{Adverse events}

A pooled analysis of the most frequent adverse events is detailed in TABLE 3. Overall, intestinal secretagogues showed to be safe drugs, without a significant proportion of serious adverse events reported. By far, the most common adverse event - which caused drop outs throughout most of the included studies - was diarrhea along with abdominal pain and nausea.

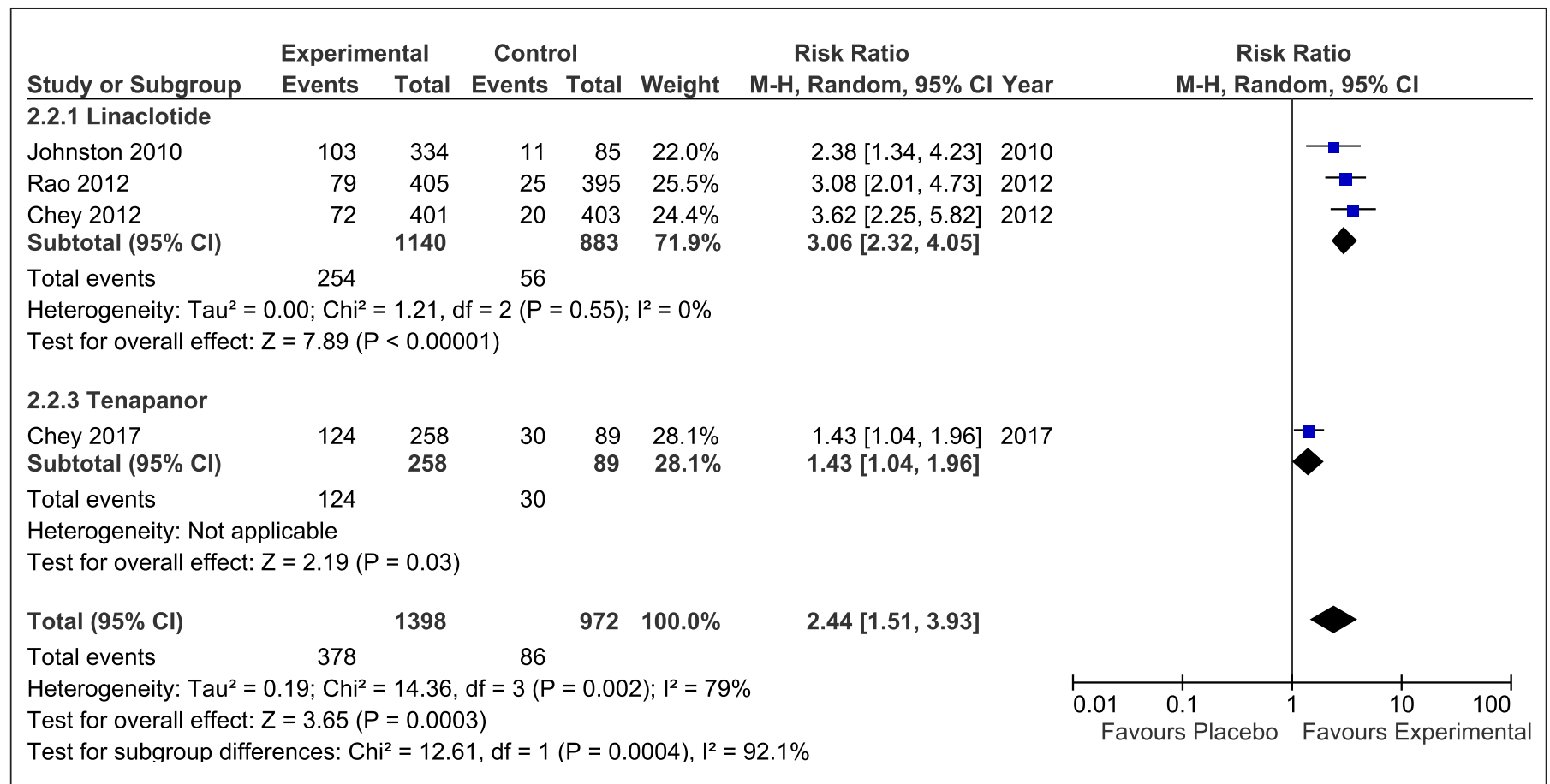

FIGURE 3. Efficacy of intestinal secretagogues on irritable bowel syndrome patients, based on the following endpoints: A) Increase in CSBM per week.

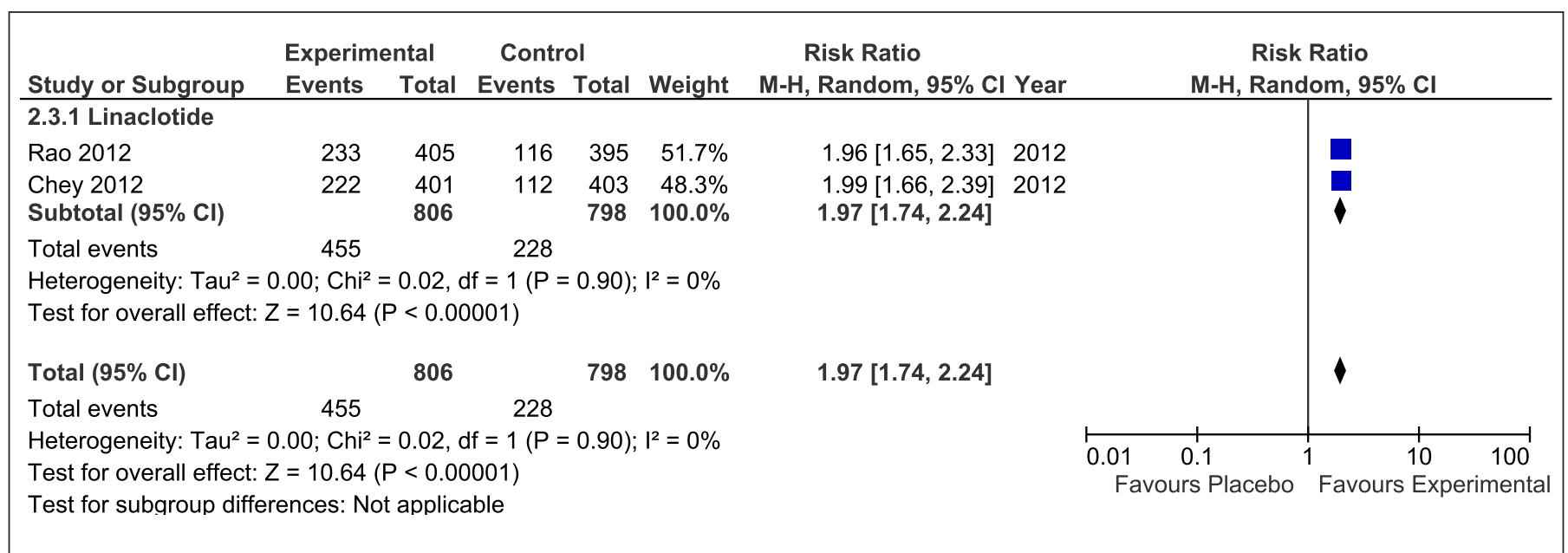

FIGURE 3. B) Achievement of $>3$ SBM per week. 


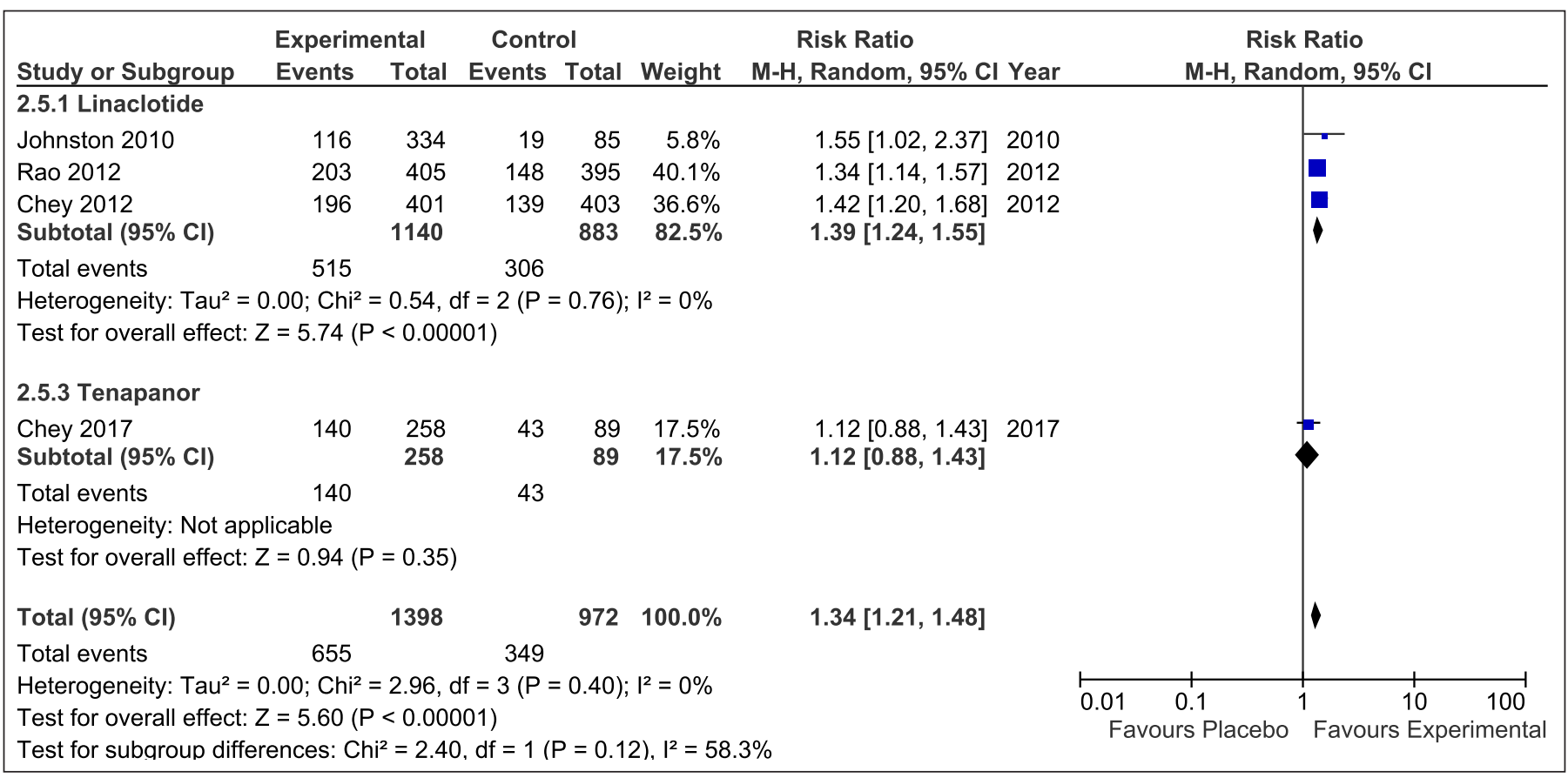

FIGURE 3. C) Improvement of abdominal pain; D) SBM after medication intake.

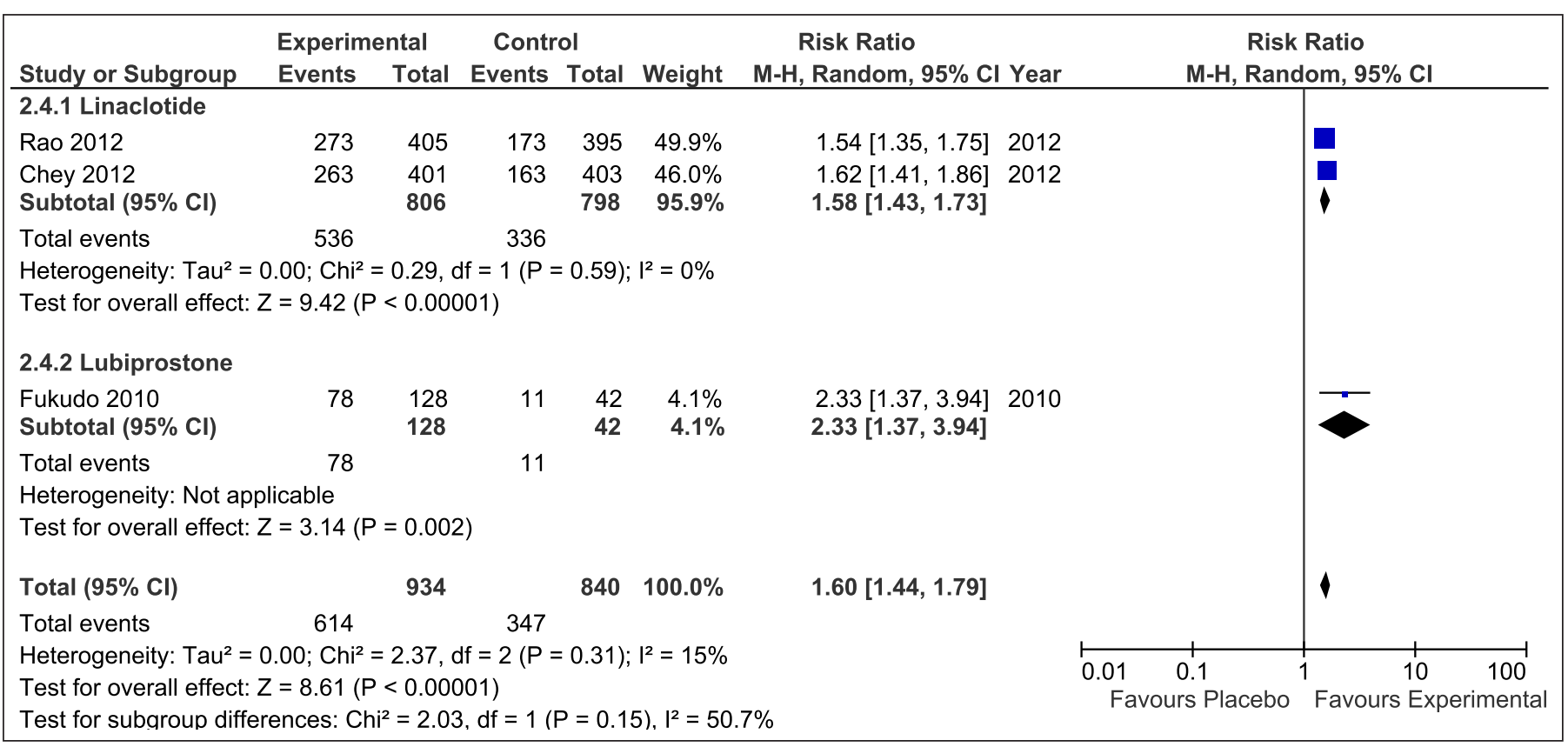

FIGURE 3. D) SBM after medication intake.

\section{DISCUSSION}

Constipation - in the context of CC or IBS-C - can be a very challenging condition to treat, leading to an impaired quality of life in a non-neglectable proportion of patients ${ }^{(2)}$. One of the reasons for this difficulty in the treatment is the paucity of therapeutic alternatives available. Most of the treatment options consist of laxatives as well as bulky agents such as fiber, which constitute a heterogeneous group of medications directed towards increasing the amount of water in stools or increasing colonic wall motility. A meta-analysis by Lee-Robichaud et al. ${ }^{(28)}$ showed that, among the afore-mentioned options, polyethylene glycol was the laxative that showed more consistent results in terms of both efficacy and safety for the treatment of CC. Nevertheless, available alternatives other than laxatives are not abundant. 
TABLE 3. Adverse events rates versus placebo.

\begin{tabular}{|c|c|c|c|c|c|c|c|}
\hline $\mathrm{AE}$ & $\begin{array}{l}\text { Number } \\
\text { of studies }\end{array}$ & $\begin{array}{c}\text { Number of } \\
\text { patients on } \\
\text { experimental drug }\end{array}$ & $\begin{array}{l}\text { Number of patients } \\
\text { on experimental } \\
\text { drug and AE }(\%)\end{array}$ & $\begin{array}{c}\text { Number of } \\
\text { patients on } \\
\text { placebo }\end{array}$ & $\begin{array}{c}\text { Number of patients } \\
\text { on placebo } \\
\text { and AE (\%) }\end{array}$ & RR & CI 95\% \\
\hline \multicolumn{8}{|l|}{ LINACLOTIDE } \\
\hline Diarrhea & 6 & 2235 & 722 & 1377 & 47 & 9.46 & $7.1-12.61$ \\
\hline Abdominal pain & 6 & 2235 & 106 & 1377 & 45 & 1.45 & $1.03-2.04$ \\
\hline Flatulence & 5 & 1900 & 89 & 1292 & 41 & 1.47 & $1.02-2.18$ \\
\hline Diarrhea & 8 & 1691 & 131 & 1055 & 14 & 5.83 & $3.38-10.1$ \\
\hline Nausea & 7 & 1663 & 162 & 1029 & 42 & 2.38 & $1.71-3.32$ \\
\hline Abdominal pain & 6 & 779 & 51 & 626 & 19 & 2.15 & $1.28-3.61$ \\
\hline \multicolumn{8}{|l|}{ PLECANATIDE } \\
\hline \multicolumn{8}{|l|}{ TENAPANOR } \\
\hline Diarrhea & 1 & 266 & 28 & 90 & 0 & N/A & N/A \\
\hline Nausea & 1 & 266 & 13 & 90 & 1 & 4.39 & $0.58-33.15$ \\
\hline Abdominal pain & 1 & 266 & 11 & 90 & 2 & 1.86 & $0.42-8.23$ \\
\hline
\end{tabular}

AE: adverse event.

Agents that promote adequate colonic motility such as 5-HT agonists have not been widely used until recently, mainly due to the concerns related to their potential cardiac side effects - as shown by the cisapride experience ${ }^{(7)}$. Prucalopride - a selective 5-HT4 agonist - has been approved by the European Medicines Agency for the treatment of $\mathrm{CC}$ due to its safety profile, showing no cardiac adverse events. Although prucalopride has expanded the therapeutic horizons for the treatment of CC or IBS-C, it may not be suitable or effective for every case that do not respond to laxatives or dietary measures.

Intestinal secretagogues are a type of medications whose mechanism of action implicates an increased amount of water excreted through the colonic epithelium. This is achieved by different means: linaclotide is a guanylate-cyclase agonist, whereas lubiprostone activates CIC-2 chloride channels, leading to the above-mentioned effect. Both plecanatide and tenapanor have been recently tested: plecanatide is also a guanylate-cyclase agonist like linaclotide ${ }^{(2)}$; tenapanor in change inhibits sodium intake by intestinal epithelial cells, by inhibiting the sodium-proton exchanger NHE3 ${ }^{(27)}$. According to our result, regardless of the molecular approach these drugs have, intestinal secretagogues are more effective than placebo for the treatment of CC and IBS-C. This conclusion becomes relevant since evidently the mechanism exerted by these drugs is an effective one, thus it may provide significant information towards the design of new drugs with a similar mechanism. Moreover, these drugs seem to have acceptable safety profiles: there is a logical increase in the risk of gastrointestinal symptoms, which do not seem to represent a major threat to the patients under treatment.

Some interesting points should be mentioned when analyzing this systematic review. First of all, even though all of the clinical trials involved showed high quality from a methodological point of view, a non-neglectable heterogeneity in terms of outcome measurement was observed. With the exception of two trials ${ }^{(16,17)}$ which adopted Food and Drug Administration's suggested endpoints, none of the included studies evaluated the outcomes in a uniform fashion - this is a relevant point when it comes to comparing the results of different trials and when meta-analyses are performed. An effort should be made for future trials to reach a consensus regarding endpoint consideration and measurement.

On the other hand, there is relevant information which has not been exhaustively assessed. As highlighted in TABLE 1, the vast majority of patients were allowed to receive rescue medications; and even though intestinal secretagogues showed a better performance in every single endpoint under consideration, the comparison of the amount of rescue medicine needed in both therapeutic arms becomes a valuable piece of information in a clinical scenario in which most endpoints are subjective - this information is not present in most of the clinical trials.

According to our results, it becomes clear that intestinal secretagogues are a useful tool for the treatment of $\mathrm{CC}$ and IBS-C. However, the exact place in the therapeutic algorithm of constipation-related syndromes is not clear. Placebo-controlled trials do not answer the question of whether these drugs are suitable to become first-line therapies. For this purpose, head to head comparisons between experimental drugs and standard of care treatments (such as polyethylene glycol for instance) are needed. There is a noticeable lack of evidence involving head to head comparisons: a network meta-analysis (with its obvious limitations) did not find any advantage among therapeutic alternatives for $\mathrm{CC}^{(29)}$. This network meta-analysis can arguably replace the need for non-inferiority clinical trials comparing different therapeutic approaches - prokinetics, laxatives, intestinal secretagogues. 
In conclusion, intestinal secretagogues are both useful and safe for the treatment of both CC and IBS-C. A significant heterogeneity in terms of outcome measurement was observed, which can be detrimental for pooled analysis and therefore efforts should be made towards unifying endpoint selection criteria. Finally, head to head comparisons are necessary in order to establish a stepwise algorithm for the management of patients with CC and IBS-C.

\section{Authors' contribution}

Lasa JS: study design, bibliographic coordination, statistical analysis. Altamirano MJ: bibliographic search, data input. Bracho LF: bibliographic search, data input. Paz S: bibliographic search, data input. Zubiaurre I: study design, critical review of draft.

Lasa JS, Altamirano MJ, Bracho LF, Paz S, Zubiaurre I. Eficiência e segurança de secretagogos intestinais para constipação crônica: uma revisão sistemática e meta-análise. Arq Gastroenterol. 2018. Ahead of print.

RESUMO - Contexto - Os secretagogos intestinais têm sido testados para o tratamento da constipação crônica e síndrome do intestino irritável com constipação predominante. O efeito classe desses tipos de drogas ainda não foi estudado. Objetivo - Determinar a eficácia e a segurança de secretagogos intestinais para o tratamento da constipação crônica e síndrome do intestino irritável de constipação predominante. Métodos - Realizada pesquisa baseada em banco de dados de trabalhos publicados entre 1966 e setembro de 2017. A estratégia de pesquisa consistia dos seguintes termos MeSH: secretagogos intestinais OU linaclotide OU lubiprostona OU plecanatide OU tenapanor OU canal de cloro E constipação crônica OU síndrome do intestino irritável. Os dados foram extraídos como análises de intenção de tratar. Um modelo de efeitos aleatórios foi usado para dar uma estimativa mais conservadora do efeito das terapias individuais, permitindo a qualquer heterogeneidade entre os estudos. Os desfechos foram descritos como risco relativo de alcançar uma melhoria no sintoma em consideração. Resultados - A busca no banco de dados rendeu 520 citações bibliográficas: 16 ensaios foram incluídos para análise, que incluiu 7658 pacientes. Doze trabalhos avaliaram a eficácia de secretagogos intestinais para constipação crônica. Estes foram melhores do que placebo, alcançando um aumento no número de evacuações completas espontâneas por semana [RR 1,87 (1,24-2,83)], para a aquisição de três ou mais evacuações espontâneas por semana [RR 1,56 (1,31-1,85)] e na indução espontânea do movimento intestinal após a ingestão de medicação [RR 1,49 (1,07-2,06)]. Resultados semelhantes foram observados ao avaliar a eficácia de secretagogos intestinais na síndrome do intestino irritável de constipação predominante com base em resultados de seis ensaios. Conclusão - Os secretagogos intestinais são alternativas terapêuticas úteis e seguras para o tratamento de síndromes relacionadas à constipação.

DESCRITORES - Constipação intestinal. Síndrome do intestino irritável. Colo.

\section{REFERENCES}

1. Vakil N, Stelwagon M, Shea EP, Miller S. Symptom burden and consulting behavior in patients with overlapping functional disorders in the US population. United European Gastroenterol J 2016;4:431-22.

2. Enck P, Leinert J, Smid M, Kohler T, Schwille-Kiuntke J. Somatic comorbidity in chronic constipation: more data from the GECCO study. Gastroenterol Res Pract 2016;2016:5939238.

3. Drossman DA. Functional Gastrointestinal Disorders: history, pathophysiology, clinical features and Rome IV. Gastroenterology 2016;Feb 1. pii: S00165085(16)00223-7.

4. Holtmann GJ, Ford AC, Talley NJ. Pathophysiology of irritable bowel syndrome Lancet Gastroenterol Hepatol. 2016;1:133-46.

5. Jadallah KA, Kullab SM, Sanders DS. Constipation-predominant irritable bowe syndrome: a review of current and emerging drug therapies. World J Gastroenterol. 2014;20:8898-909.

6. Mearin F, Ciriza C, Minguez M, Rey E4, Mascort JJ5, Peña E, et al. Clinical practice guideline: irritable bowel syndrome with constipation and functional constipation in the adult. Rev Esp Enferm Dig. 2016;108:32-63.

7. Aboumarzouk OM, Agarwal T, Antakia R, Shariff U, Nelson RL. Cisapride for intestinal constipation. Cochrane Database Syst Rev. 2011;(1):CD007780.

8. Ryu HS, Choi SC. Recent updates on the treatment of constipation. Intest Res. 2015;13:297-305.

9. Love BL, Johnson A, Smith LS. Linaclotide: a novel agent for chronic constipation and irritable bowel syndrome. Am J Health Syst Pharm. 2014;71:1081-91.

10. Jin Y, Blikslager AT. ClC-2 regulation of intestinal barrier function: translation of basic science to therapeutic target. Tissue Barriers. 2015;3(4):e1105906.

11. Thomas RH, Luthin DR. Current and emerging treatments for irritable bowel syndrome with constipation and chronic idiopathic constipation: focus on prosecretory agents. Pharmacotherapy. 2015;35:613-30.

12. Schoenfeld P, Cook D, Hamilton F, Laine L, Morgan D, Peterson W. An evidence-based approach to gastroenterology therapy. Gastroenterology. 1998;114:1318-25.

13. Johnston JM, Kurtz CB, MacDougall JE, Lavins BJ, Currie MG, Fitch DA, et al. Linaclotide improves abdominal pain and bowel habits in a phase IIb study of patients with irritable bowel syndrome with constipation. Gastroenterology. 2010;139:1877-86
14. Lembo AJ, Kurtz CB, MacDougall JE, Lavins BJ, Currie MG, Fitch DA, et al. Efficacy of linaclotide for patients with chronic constipation. Gastroenterology. 2010;138:886-95

15. Lembo AJ, Schneier HA, Shiff SJ, Kurtz CB, MacDougall JE, Jia XD, et al. Two randomized trials of linaclotide for chronic constipation. N Engl J Med. 2011;365:527-36

16. Chey WD, Lembo AJ, Lavins BJ, Shiff SJ, Kurtz CB, Currie MG, et al. Linaclotide for irritable bowel syndrome with constipation: a 26-week, randomized, double-blind, placebo-controlled trial to evaluate efficacy and safety. Am J Gastroenterol. 2012;107:1702-12.

17. Rao SS, Lembo AJ, Shiff SJ, Lavins BJ, Currie MG, Jia XD, et al. A 12-week, randomized, controlled trial with a 4-week randomized withdrawal period to evaluate the efficacy and safety of linaclotide in irritable bowel syndrome with constipation. Am J Gastroenterol. 2012;107:1714-24.

18. Johanson JF, Morton D, Geenen J, Ueno R. Multicenter, 4-week, double-blind, randomized, placebo-controlled trial of lubiprostone, a locally-acting type-2 chloride channel activator, in patients with chronic constipation. Am J Gastroenterol. 2008;103:170-7.

19. Drossman DA, Chey WD, Johanson JF, Fass R, Scott C, Panas R, Ueno R. Clinical trial: lubiprostone in patients with constipation-associated irritable bowel syndrome - results of two randomized, placebo-controlled studies. Aliment Pharmacol Ther. 2009;29:329-41.

20. Fukudo S, Hongo M, Kaneko H, Ueno R. Efficacy and safety of oral lubiprostone in constipated patients with or without irritable bowel syndrome: a randomized, placebo-controlled and dose-finding study. Neurogastroenterol Motil. 2011;23:544-e205.

21. Ondo WG, Kenney C, Sullivan K, Davidson A, Hunter C, Jahan I, et al. Placebo-controlled trial of lubiprostone for constipation associated with Parkinson disease. Neurology. 2012;78:1650-4.

22. Cryer B, Katz S, Vallejo R, Popescu A, Ueno R. A randomized study of lubiprostone for opioid-induced constipation in patients with chronic noncancer pain. Pain Med. 2014;15:1825-34

23. Fukudo S, Hongo M, Kaneko H, Takano M, Ueno R. Lubiprostone increases spontaneous bowel movement frequency and quality of life in patients with chronic idiopathic constipation. Clin Gastroenterol Hepatol. 2015;13:294-301. 
24. Jamal MM, Adams AB, Jansen JP, Webster LR. A randomized, placebo-controlled trial of lubiprostone for opioid-induced constipation in chronic noncancer pain. Am J Gastroenterol. 2015;110:725-32.

25. Christie J, Shroff S, Shahnavaz N, Carter LA, Harrison MS, Dietz-Lindo KA et al. A randomized, double-blind, placebo-controlled trial to examine the effectiveness of lubiprostone on constipation symptoms and colon transit time in diabetic patients. Am J Gastroenterol. 2017;112:356-64.

26. Miner PB, Koltun WD, Wiener GJ, De La Portilla M, Prieto B, Shailubhai K, et al. A randomized phase III clinical trial of plecanatide, a uroguanylin analog, in patients with chronic idiopathic constipation. Am J Gastroenterol. 2017;112:613-21
27. Chey WD, Lembo AJ, Rosenbaum DP. Tenapanor treatment of patients with constipation-predominant irritable bowel syndrome: a phase 2, randomized, placebo-controlled efficacy and safety trial. Am J Gastroenterol. 2017;112:763-74

28. Lee-Robichaud H, Thomas K, Morgan J, Nelson RL. Lactulose versus polyethylene glycol for chronic constipation. Cochrane Database Syst Rev 2010;7:CD007570.

29. Nelson AD, Camilleri M, Chirapongsathorn S, Vijayvargiya P, Valentin N, Shin A, et al. Comparison of efficacy of pharmacological treatments for chronic idiopathic constipation: a systematic review and network meta-analysis. Gut. 2017;66:1611-22. 